\title{
International migration: The state-sovereignty-migration nexus
}

\author{
$D$ CHIGUDU ${ }^{l}$
}

\begin{abstract}
Commonly, international human migration is blamed for corroding states sovereignty, especially stemming from policy circles, academic literature and citizens of the host countries. This has attracted the attention of the media highlighting hazards of being a migrant, with some countries viewing migrants as enemies; and, Cuba provides a vivid case. Yet in other countries, migrants are viewed as important contributors to social and economic development, with Mexico, the Dominican Republic and India serving as examples. This article locates migrants in the framework of human rights as guided by international law without prejudice to the demands of state sovereignty, but linking the two in the context of developing international standards. Migration is seen as a feature of human history dating back to primordial time. Nothing appears surprising in the movement of people across borders, defining a migrant through emigration and immigration while giving due respect to the sovereignty of states, both sending and receiving. The article discusses the nexus between migrants and state sovereignty in order to highlight the mutual benefit grounded in international law. It attempts to portray a more positive image of the migrant person in light of the global world, socio-economic development and human rights fundamentals. The main challenge remains that of implementing human rights, which appear to be at the crossroads of individual rights and state sovereignty. The paper reveals how the challenge can be overcome while maintaining the structure of rights and freedoms without infringement on states' sovereignty. It concludes that migrants remain on the periphery of effective protection from the vagaries of the citizens, partly because the state has a tendency to confine certain rights to its citizenry. States possess discretionary authority to control the ingress of foreign nationals into their territories though sometimes they fail to do that as evidenced by hundreds of millions of irregular migrants around the world. The paper reveals that, the symbiotic relationship between migrants, regular or irregular, and state sovereignty should be strengthened.
\end{abstract}

Keywords: state sovereignty, migration, migrant, rights

\section{Introduction}

International migration is growing owing to a number of factors and manifests, as one of the most constant social process. IOM (2010: xix) suggests that these factors include "a result of growing demographic disparities, the effects of environmental change, new global political and economic dynamics, technological revolutions and social networks". It estimates that the number of migrants in the first decade of the $21^{\text {st }}$ century grew from 150 million to 214 million worldwide and suggests that this growth is likely to continue into the future. The IOM (2003) reported that, at the beginning of the $21^{\text {st }}$ century, one out of every 35 persons worldwide was a migrant. While according to Zentella \& Schiesser (2005), the Population

1 Department of Public Administration \& Management, University of South Africa, P.O. Box 392, Unisa, 0003, South Africa, E-mail: dancing@gmail.com 
Division of the United Nations estimated the total number of international migrants at approximately 175 million, including refugees and displaced persons, but not the irregular migrants who were not counted in official statistics. Gilligan (2012) contends that this migration is believed to be undermining the sovereignty of states and corroborates Castles \& Miller's (2009: 3) portrayal of "the challenge posed by international migration to the sovereignty of states, specifically to their ability to regulate the movement of people across their borders."

The view that the sovereignty of states is being undermined is exacerbated by the media reports in Western Europe and other affluent parts of the world (Gilligan 2012), regarding immigration as invasion, mafias, unemployment, violence, crime, drug trafficking, backwardness and illegality (Van Dijk, 2007). However, some scholars dismiss the idea of migrants presenting a challenge to state sovereignty because the power to determine who enters the border of a country resides in the national sovereignty (Munck, 2008). A case in point is noted by Flynn (2005) that, in the United Kingdom's recent policy developments there has been provision for migrant access to jobs, family reunification, welfare services with realistic prospects for ultimate integration and acquisition of citizenship.

Issues surrounding migration and migrants have had complexities in the way they are handled by the nationals the world over. To Bustamante (2010), in some instances the issues revolve around structurally vulnerable abuses of migrants as non-citizens, weighing heavily on those with undocumented status. These abuses are compounded with political manipulations and recurrent economic crises. Chetail (2013) observes that, the last decade has witnessed an increase in the awareness of migrants' vulnerabilities with corresponding measures to ensure due respect for migrant rights and privileges. A number of measures and initiatives have resulted in states and international organisations developing instruments making migrants rights "more clearly recognisable as human and labour rights" (Cholewinski, 2010: 614). On the other hand, the "universal respect for, and observance of human rights and fundamental freedoms for all without distinction" is provided for as one of the basic principles of the international legal order of the UN Charter Article 55 Paragraph C. Despite this provision, a lot remains to be done practically through domestic laws to draw all the normative and practical consequences for those who are not nationals of the country in which they live. This is a challenge that receiving countries may have to live with. In another dimension, Brainard \& Brinkerhoff (2006) view the challenge to state sovereignty as stemming from both globalisation and localism and that, challenges are directed from above and from below the national level. They argue that, "among the many challenges to state sovereignty, three trends are often highlighted: migration, information technology, and the emergence of universal values that increasingly inform international law" (Brainard \& Brinkerhoff, 2006: 595). Although these three trends are often highlighted as challenges to the evolving complexity of state sovereignty they may not necessarily be challenges. The various definitions may help locate the link between state sovereignty and migration. State sovereignty as a legal construct has been described as a theory (Fox, 1997), an empirical reality (Philpott, 1997) and a multifaceted concept (Heller \& Sofaer 2001; Montgomery, 2002). But Krasner (1999, 2001) describes state sovereignty in its broadest sense as concerning the definition of authority, the criteria for becoming such an authority and the prerogatives of these authorities.

This paper aims to locate migrants and refugees within the context of state sovereignty and human rights. Based on the principle of nondiscrimination as fundamental, the thrust is on analysing those provisions enshrined in the basic human rights instruments purporting to exclude migrants. The purpose is to dwell on the justification for the distinctions emerging in 
recent state practices on the strength of state sovereignty while considering the usefulness of the migrant worker, undocumented migrants, asylum seekers and refugees against a system of rights. These rights, according to Goodwin-Gill (1989), include freedom of movement, rights to leave and to return to one's country, not to be expelled, not to be returned to a country in which life or freedom to one's country may be endangered, to seek refuge and asylum and "procedural" rights. Procedural rights would entail equal protection under the law, the right to work, political rights, freedom of thought and conscience, association and cultural rights that relate to education, community rights and language.

\section{Background: International law on migration}

It is interesting to note that the legal protection of migrants dates back to the history of international law when the term "jus gentium" designated rules for the legal status of migrants during the law of ancient Rome. According to Chetail (2013), this Latin expression was used to denote the law of nations before "international law" was coined by Jeremy Bentham in 1789. In practice and principle, migrants belong to the dual dependency of the state where they temporarily stay and to that where they have the nationality. There is an overlap between the territorial and personal jurisdictions which is inherent to alienage. Further, the human rights law provides for equality of treatment between citizens and migrants in accordance with the national standards. The General Assembly adopted the Declaration on the Human Rights of Individuals who are migrants. This was done in December 1985 through resolution 40/144. The UN General Assembly has further reaffirmed "the need for all States to protect fully the universally recognised human rights of migrants, especially women and children, regardless of their legal status." The practice is however still incomplete as it is evolutionary in nature.

Article 1 of the 1948 Universal Declaration of Human Rights opens with the affirmative that, "All human beings are born free and equal in dignity and rights". Also, the preamble to the Charter of the United Nations provides for the determination "to reaffirm faith in fundamental human rights, in the dignity and worth of the human person". Brownlie (1983a) observes that, the Annex to the ILO Constitution affirms that "all human beings irrespective of race, creed or sex have the right to pursue both their material well-being and their spiritual development in conditions of freedom and dignity of economic security and of equal opportunity". Furthermore, as Sieghart (1983:10) observes, "it is the recognition that all human beings differ from each other, and that each individual is unique, which underlies the concept of the integrity and dignity of the individual person which human rights law is primarily concerned to protect".

These provisions in the international law appear to be challenges for both receiving and sending countries. This led Sheffer (1985) to conclude that migrants are not necessarily politically good news for the government of a sending country; and, that they are also not necessarily good news for the hosting country. They have become a political factor to be taken account of by both countries. Migrants come in different categories, ranging from those highly educated professionals seeking better working conditions, political refugees fleeing persecution to economic refugees escaping poverty and hunger. All these categories are motivated by the desire to improve their lives or escape violence. In some developed countries, migrants have contributed immensely to the economic growth; and, the United States of America is a living testament (Panjabi, 2010). To Panjabi (2010: 2), "If this planet ever progresses to the point where people consider themselves citizens of the world, the impetus for that internationalised being will have come from this contact with diversity,

Td, 10(4), December 2015, Special edition, pp. 1-29 
fueled by migration." Migrants, to this end, could be a vehicle to globalisation and development, if properly managed by the hosting countries.

\section{State sovereignty and human rights}

State sovereignty is premised on the concept that, all states are equal and independent. Traditionally, the notion has been considered the foundation of international law. Brownie (2003b: 287) describes sovereignty as:

\section{"(1) A jurisdiction, prima facie exclusive, over a territory and the permanent population living there; (2) a duty of non-intervention in the area of exclusive jurisdiction of other states; and (3), the dependence of obligations arising from customary law and treaties on the consent of the obligor".}

Therefore, what is critical in state sovereignty is the state's control over its territory as well as the sovereign right to control the movement of migrants. However, Lillich (1984) points out that, although there is a distinct manifestation between nationals and migrants in most legal systems, migrants have been granted rights as societies have desired their presence for trade reasons, reciprocity or for diplomatic protection.

Some legal instruments laying down standards for the protection of migrants have been developed. For instance, the United Nations provides such protection through the International Convention on the Protection of the Rights of all Migrant Workers and their Families (1990); the International Labour Organisation (ILO) does so in the Convention on Migrant Workers (1975); and, the Council of Europe through the European Convention on the Legal Status of Migrant Workers (1977). The effectiveness of these legal instruments has not been realised as expected because they depend on ratification by individual states (Cator \& Niessen, 1994 cited in Morris (1997). The ratification may easily be done by sending rather than receiving states. It is within the powers of states to determine the terms of who can legitimately enter the territory, duration of stay and if the migrant can or cannot undertake paid employment (IOM, 2010). To Fekete (2009), states can detain migrants who do not adhere to their terms or they can expel them from their territory. This practice is common in many parts of the world and South Africa. In this regard, a state restrains or structures the opportunities available to immigrants (Gilligan, 2012). This implies that; migrants/immigrants are objects whose actions and functions are directed by the actions of the state.

Weiner (1985) argues that, states may actually promote the influx of migrants to increase their population or to fill a temporary demand for labour. Some countries advanced countries, such as Australia and New Zealand, have experienced that practice in the $19^{\text {th }}$ and early $20^{\text {th }}$ centuries. Western European countries solicited for migrant labour from Greece, Turkey, North Africa, during the period 1950s-1960s. In the period 1970s-1980s, the oil producing Persian Gulf countries also actively sought migrant labour from the Arab States and Asia. The Israeli state promotes immigration of Jews regardless of their country of origin in order to fulfill its nationalist ideology of creating a homeland of Jews (Weiner, 1985). States may encourage their citizens to seek employment abroad as a way to relieve unemployment and boost remittances. Examples are India, Bangladesh, Sri Lanka and Pakistan whose governments promote migration to the Middle East. The Turkish government has promoted migration to Germany and, in Africa, the Algerian government has promoted migration to France. 
The preamble of the American Convention of Human Rights (cited in Chetail, 2013: 243) states that, "the essential rights of man are not derived from one's being a national of a certain state, but are based upon attributes of the human personality." This is reinforced by the principle of non-discrimination, endorsed in all human rights treaties including Article 2(1) of the International Covenant on Civil and Political Rights (ICCPR). The principle is a well-recognised norm of general international law whose impact on the legal position of noncitizens is quite clear and straightforward. But, even when lawfully within the territory, a migrant may still be deported from that territory if some procedural guarantees are not fulfilled. The question of whether a migrant is lawfully within the territory or not is determined by domestic law. The 1981 African Charter on Human and Peoples Rights as well as the 1988 Additional Protocol to the American Convention on Human Rights in the Area of Economic, Social and Cultural Rights guarantee the right to work without any discrimination.

Despite all these provisions, the International Labour Organisation (ILO) drew a list of challenges migrants currently face (Zentella \& Schiesser, 2005: 5). Although the list is not exhaustive, it includes among others, the following challenges: a deterioration of human security and increased human displacement; increased exploitation of migrants and lack for respect for basic human rights; manifestation of xenophobic hostility; increased trafficking in human beings; an exodus of well-educated professionals (brain drain); feminisation of migration, with female migrants now accounting for nearly half of all migrants. To these challenges, Zentella \& Schiesser (2005) added their concern about the increase in the number of migrant children, particularly unaccompanied minors. South African Immigrations laws have been amended in 2015 to address this concern.

According to Vietti (2013), the complexity of the challenges discussed above are highlighted by the traditional distinction between "voluntary" migrants or "free population movements" and "forced" or "involuntary." Forced migrants are driven from their home countries by war, violent conflicts, human rights violations and abuses or discrimination (Fisher et al., 1997). For voluntary migrants, it is assumed that the movement is a result of free choice rather than force. In reality, social, political,-and economic insecurity can compel people to move from one place to another. They move even in the absence of overt forms of persecution or force associated with involuntary migration. Kothari (2002: 20) posits that, although all forms of migratory acts appear to be "voluntary," in "reality the decision to move is made within a context where the individual or group is faced with no alternatives since staying in situ is not a realistic option." This view invalidates the attempt to categories migrants as voluntary or involuntary.

\section{State sovereignty-migration nexus}

The existing international law on migration does not undermine state sovereignty by protecting human rights as may be feared. The law does not dictate upon states how to control migration flows, nor does it impose on how to formulate migration rules and regulations. What the law does is to prescribe that states ought to develop migration laws that protect and manage the rights of both documented and undocumented migrants. Migration management laws should not infringe on fundamental human rights enshrined in the international law provided by various instruments discussed in this article. These laws should also not compromise the security and public order of the state. For instance, there are practices that protect human rights of irregular immigrants such as human trafficking, 
curbing corruption by immigration officers at border posts and in the Department of Home Affairs.

Goodwin-Gill (1989: 529-30) cites Musgrove v. Chun Teeong Toy (1891) case in which the Privy Council denied the proposition that any migrant had any right to enter British territory; and, in Nishimura Ekiu v. United States (1892) the Supreme Court concluded:

"It is an accepted maxim of international law, that every sovereign nation has the power, as inherent in sovereignty, and essential to its self-preservation, to forbid the entrance of foreigners within its dominions, or to admit them only in such cases and upon such conditions as it may see fit to prescribe".

In the judgments above, migration control as it was then, still obtains to this day. It is directed towards mostly potential migrants from the developing world apart from those with desirable qualifications. The controls come hard upon a long time in which receiving states have profited hugely from the labour of the same or similar environments (Goodwin-Gill, 1989). States today, laments Goodwin-Gill (1989), are quite vocal in their need for controls on migrants. Yet they are less vocal in their obligations towards these migrants within their countries, such immigrants have and continue to contribute to their economic well-being of host societies.

Zilbershats (2010) notes that, the international law of human rights provides for every person to leave any country including his own. It does provide for states to allow entry and perhaps accord permanent residents. For a person to enter as a tourist or an immigrant the discretion lies with the state with the exception to this provision being the right given to refugees in terms of the 1951 Convention on the Status of Refugees. The Convention provides for the principle of non-refoulment of people who enter the state within its ambit (that is, not to expel refugee migrants). Globalisation is about blurring of boundaries or de-bordering (Zilbershats, 2010) to promote the interconnectedness of the world with speed and high frequency in exchange of goods, technology, labour and services. Empowering states to control entry of migrants in the principle of state sovereignty presents challenges to the globalisation phenomenon. To Sur (1997), societies can prosper in a globalised world. The interdependence brings about cultural homogeneity and increased ideological, economic solidarity. Globalisation carries many benefits and, it explains why Europe's de-bordering model provides flexibility to migration rules from one country to another.

Betts (2009) concludes that although state sovereignty remains at the centre of world politics, it is no longer absolute, in the wake of global governance. Global governance is manifested by the formation of supranational bodies like the United Nations, the World Trade Organisation, and regional blocs like the European Union, the African Union, the Southern African Development Community, and the North American Free Trade Agreement among others. Foreign nationals are increasingly crossing state borders despite international recognition of powers vested in states to control their ingress. They cross borders in thousands yearly without express permission from the authorities. The majority of these migrants crossing the borders under such circumstances ultimately get employed. According to Bosniak (1991), irregular migration is unlikely to diminish anytime soon. This could be due to the fact that, undocumented migrant labour is increasingly relied on by advanced and developing states (Sassen, 1989). There is need to strengthen the symbiotic relationship between migrants and state sovereignty. 


\section{Conclusion}

The rule of state sovereignty is fundamentally a governing principle guided by international legal and political systems. It refers primarily to a state's power for exercising exclusive control over its jurisdiction, subject to limitations provided for by international law. Migrants are viewed as those people who move from one state to another in search of jobs or better living conditions. While theorists on globalisation put emphasis on de-bordering and international linkages they remain ambivalent about the nexus between migration and national sovereignty. This article reviewed migration in the context of state sovereignty and globalisation. Although the term sovereignty is so diverse, it remains embedded at the centre of world politics and yet less absolute due to the fast growing trends of globalisation. Some states are seeing value in the migrants and granting them citizen status, including associated privileges. These actions reassert rather than diminish state sovereignty. Further, such actions represent expansion of sovereign authority because these extraterritorial citizens become legitimate stakeholders under the dominion of that nation-state.

\section{References}

Betts, A. 2009. Forced Migration and Global Politics. Chichester, Sussex, UK: WileyBlackwell.

Bosniak, L.S. 1991. Human rights, state sovereignty and the protection of undocumented migrants under the International Migrant Workers Convention. International Migration Review, 25(4): 737-770.

Brainard, L.A. \& Brinkerhoff, J.M. 2006. Sovereignty under siege, or a circuitous path for strengthening the state? Digital diasporas and human rights. International Journal of Public Administration, 29: 595-618.

Brownlie, I. 1983a. Basic Documents in International Law. Oxford: Clarendon Press.

Brownlie, I. 2003b. Principles of Public International Law, $7^{\text {th }}$ ed. Oxford: Oxford University Press.

Bustamante, J.A. 2010. Extreme vulnerability of migrants: The cases of the United States and Mexico. 24 GEO. IMMIGR. L.J, 565: 565-66.

Castles, S. \& Miller, M.J. 2009. The Age of Migration: International Population Movements in the Modern World. Houndsmills: Palgrave/Macmillan.

United Nations, n.d. Chapter IX: International Economic and Social Co-operation, http://www.un.org/en/documents/charter/chapter9.shtml [Accessed: 15 August 2015].

Chetail, V. 2013. The human rights of migrants in General International Law: From Minimum Standards to Fundamental Rights. Georgetown Immigration Law Journal, 28(1): 225-255.

Cholewinski, R. 2010. Human rights of migrants: The dawn of a new era? 24 GEO.IMMIGR. L.J, 585: 585-615.

Fekete, L. 2009. A Suitable Enemy: Racism, Migration and Islamophobia in Europe. London: Pluto.

Fisher, P., Reiner, M. \& Straubhaar, T. 1997. Should I stay or should i go? In Brochmann, G., Tamas, K. \& Hammar, T. (eds.), International Migration, Immobility and 
Development: Multidisciplinary Perspectives. New York, NY: Berg Publishers, pp. 4990.

Flynn, D. 2005. New borders, new management: The dilemmas of modern immigration policies. Ethnic and Racial Studies, 28(3): 463-490.

Fox, G.H. 1997. New approaches to international human rights: The sovereign state revisited. In Hashmi, S.H. (ed.), State Sovereignty: Change and Persistence in International Relations. University Park, PA: Pennsylvania State University Press, pp. 105-130.

United Nations, n.d. G.A. Res. 40/144, U.N. Doc. A/RES/40/144 (Dec. 13, 1985). http://www.un.org/documents/ga/res/40/a40r144.htm [Accessed: 16 August 2015].

Gilligan, C. 2012. Immigration Controls and the Erosion of Popular Sovereignty. Gritim Working Paper Series, 10. (S. C. O’Dowd, Ed.) Universitat Pompeu Fabra.

Goodwin-Gill, G.S. 1989. International law and human rights: Trends concerning international migrants and refugees. International Migration Review, 23(3): 526-546.

Heller, T.C. \& Sofaer, A.D. 2001. Sovereignty: The practitioners' perspective. In Krasner, S.D. (ed.), Problematic Sovereignty: Contested Rules and Political Possibilities. New York: Columbia University Press, pp. 24-52.

International Organisation for Migration (IOM), (2003, June). World Migration Report 2003. Route des Morillons, CH-1211 Geneva 19: International Organisation for Migration (IOM).

International Organisation for Migration (IOM), 2010. World Migration Report 2010: The Future of Migration: Building Capacities for Change. Geneva: International Organization for Migration (IOM).

Kothari, U. 2002. Migration and Chronic Poverty. Working Paper No. 16. Institute for Development, Policy and Management, University of Manchester, http:www.chronicpoverty.org/pdfs/16Kothari.pdf [Accessed: 17 August 2015].

Krasner, S. 1999. Sovereignty: Organized Hypocrisy. Princeton: Princeton University Press.

Krasner, S.D. 2001. Problematic sovereignty. In Krasner, S.D. (ed.), Problematic Sovereignty: Contested Rules and Political Possibilities. New York: Columbia University Press, pp. 123.

Lillich, R.B. 1984. The Human Rights of Aliens in Contemporary International Law. Manchester: Manchester University Press.

Montgomery, J.D. 2002. Sovereignty in transition. In John, D.G. (ed.), How Governments Respond: Sovereignty Under Challenge. New Brunswick and London: Transaction Publishers, pp. 3-30.

Morris, L. 1997. Globalization, migration and the nation-state: The path to a post-national Europe? The British Journal of Sociology, 48(2): 192-209.

Munck, R. 2008. Globalisation, Governance and Migration: An Introduction. Third World Quarterly, 29(7): 1227-1246. 
Organisation of American States, n.d. Additional Protocol to the American Convention on Human Rights in the Area of Economic, Social and Cultural Rights. Article 6, Nov. 17, 1988, O.A.S.T.S No. 69.

Panjabi, R.K. 2010. The International Migration Crisis: State Sovereignty versus Human Rights,. http://dx.doi.org/10.1080/03612759.2010.514541 [Accessed: 16 August 2015].

Philpott, D. 1997. Ideas and the evolution of sovereignty. In Hashmi, S.H. (ed.), State Sovereignty: Change and Persistence in International Relations. University Park, PA: Pennsylvania State University Press, pp. 15-47.

Sassen, S. 1989. America's Immigration Problem. World Policy Journal, 811-832.

Sheffer, G. 1985. Diasporas. London: Croom Helm.

Sieghart, P. 1983. The International Law of Human Rights. Oxford: Clarendon Press.

Sur, S. 1997. The state between fragmentation and globalisation. Eurpean Journal of International Law, 8(3): 421-434.

Van Dijk, T.A. 2007. Racism and the press in Spain. In BLAS, J.L. \& Others, Discurso y Sociedad II. Nuevas Contribuciuones al Estudio de la Lengua en un Contexto social (pp. 59-99). Castelló de la Plana: Universitat, Jaume I.

Vietti, F. 2013. Human insecurity: Understanding international migration from a human security perspective. Journal of Migration and Human Security, 1(1): 17-31.

Weiner, M. 1985. On international migration and international relations. Population and Development Review, 11(3): 441-455.

Zentella, G.T. \& Schiesser, F. 2005. Migration and development. 113 ${ }^{\text {th }}$ Assembly of the Inter-Parliamentary Union 17-19.10.2005. Geneva: Second Standing Committee CII/113/R-rev, pp. 1-9.

Zilbershats, Y. 2010. Sovereign states control of immigration: A global justice perspective. Isreal Law LAW Review, 46(126): 126-163. 